Physiol 55:1849-1853

21. Lou HC, Lassen NA. Friis-Hansen B 1978 Decreased cerebral blood flow after administration of sodium bicarbonate in the distressed newborn infant. Acta Neurol Scand 57:239-247

22. Rapoport SI 1970 Effect of concentrated solutions on blood-brain barrier. Am J Physiol 219:270-274

23. Pannier JL, Demeester MS, Leusen I 1974 The influence of nonrespiratory alkalosis on cerebral blood flow in cats. Stroke 5:324-329

24. Arvidsson S, Haggendal E, Winso 1981 Influence on cerebral blood flow of infusions of sodium bicarbonate during respiratory acidosis and alkalosis in the dog. Acta Anesthesiol Scand 25:146-152

25. Pannier JL, Weyne J, Demeester G, Leusen I 1978 Effects of non-respiratory alkalosis on brain tissue and cerebral blood flow in rats with damaged bloodbrain barrier. Stroke 9:354-359

\title{
The Responses of Glutathione and Antioxidant Enzymes to Hyperoxia in Developing Lung
}

\author{
JOSEPH B. WARSHAW, CHARLIE W. WILSON, III, KOTARO SAITO, AND \\ RUSSELLL A. PROUGH \\ Departments of Pediatrics and Biochemistry, The University of Texas Health Science Center at Dallas, \\ Dallas, Texas 75235
}

\begin{abstract}
Total glutathione levels and the activity of enzymes associated with antioxidant protection in neonatal lung are increased in response to hyperoxia. Glutathione levels in developing rat lung decreased from $24 \mathrm{nmol} / \mathrm{mg}$ protein on day 19 of gestation to approximately $12 \mathrm{nmol} /$ mg protein at birth. The initial decrease in glutathione may be due to emergence of other antioxidant systems. Newborn rats placed in $100 \%$ oxygen showed a rapid and sustained increase in total glutathione levels which was primarily due to an increase in reduced glutathione. Explants obtained from 16-wk gestation human fetal lung or from 17to 18-day fetal rat lung also showed increased total and reduced glutathione when cultured in $95 \%$ oxygen, $5 \% \mathrm{CO}_{2}$ as compared with explants cultured in room air. Type II cells isolated from neonatal rats maintained in oxygen for 6 days also showed glutathione levels twice those found in cells isolated from animals in room air. The activity of antioxidant enzymes (glucose-6-phosphate dehydrogenase, glutathione peroxidase, glutathione reductase) was increased in lungs of newborn rats exposed to $100 \%$ oxygen either at birth or 2 days of age. Antioxidant enzyme activity of lung explants cultured in $95 \%$ oxygen, $5 \% \mathrm{CO}_{2}$ was also higher than in explants maintained in room air. These results suggest that the increases in glutathione and of antioxidant enzymes in vivo and in vitro are a direct effect of oxygen exposure in lung and that the increase of both glutathione and antioxidant enzyme activity is intrinsic to the lung cell itself. It is likely that increases in glutathione in lung represent an important protective mechanism against oxidant injury. (Pediatr Res 19:819-823, 1985)
\end{abstract}

Received January 14, 1985; accepted March 21, 1985.

Reprint requests Joseph B. Warshaw, M.D., Department of Pediatrics, The University of Texas Health Science Center at Dallas, 5323 Harry Hines Boulevard, Dallas, TX 75235

Supported by National Institutes of Health Grant 5 RO1 HD17785.
Abbreviations

SOD, superoxide dismutase

GSH, reduced glutathione

GSSG, oxidized glutathione

PBS, phosphate-buffered saline

G6PHD, glucose-6-phosphate dehydrogenase

Bronchopulmonary dysplasia is a problem of clinical significance in newborns treated with high concentrations of oxygen in the course of therapy for the respiratory distress syndrome. While it is likely that factors such as positive pressure ventilation. (1) and patent ductus arteriosis (2) play an important role in chronic lung disease in newborns, the duration and intensity of oxygen exposure is thought to be a central etiological feature of bronchopulmonary dysplasia (3). The sequence of injury result-. ing initially in lung injury has been well described $(4,5)$. It has been postulated that highly reactive free radicals of oxygen such. as the superoxide anion $\left(\mathrm{O}_{2}^{--}\right)$may cause tissue injury by direct peroxidation of unsaturated fatty acids in membranes and also by oxidation and inactivation of enzymes and other cell constit-. uents essential for cell function. This results in membrane damage with transudation of fluid and formed elements into alveoli and the sequence of injury characterized by fibrosis and chronic clinical impairment.

Protective mechanisms against oxidant injury included SOD and the biological systems associated with glutathione or chemical antioxidants such as $\alpha$-tocopherol. SOD catalyzes the dismutation of the superoxide anion $\mathrm{O}_{2}^{-}$to $\mathrm{H}_{2} \mathrm{O}_{2}$ and $\mathrm{O}_{2}$. The $\mathrm{H}_{2} \mathrm{O}_{2}$ thus formed can be removed by either catalase or glutathione peroxidase. SOD is found in all cells which sustain aerobic metabolism and appears to be a first line defense against oxidant damage. In the glutathione system, GSH provides reducing, equivalents necessary for the removal of hydrogen peroxide and perhaps other toxic membrane lipid hydroperoxides through the 
action of glutathione peroxidase. GSH is replenished from GSSG by glutathione reductase using NADPH generated by enzymes such as G6PDH. These reactions are linked in concerted fashion to maintain a relatively high GSH/GSSG ratio which ultimately protects the cell from damage from hydrogen peroxide and lipid hydroperoxides. Both SOD and enzymes involved with glutathione function show increases in activity in response to hyperoxia (6) in lung tissue.

The purpose of the present investigation was to determine the sensitivity of glutathione as an indicator of oxidant exposure in lung in comparison to enzymes associated with antioxidant protection. We also compared in vivo and in vitro responses of these antioxidant systems in neonatal rats, lung explants, and alveolar type II cells.

\section{METHODS}

Animals. Timed 19-day pregnant Sprague Dawley rats were obtained from Holtzman (Madison, WI). Newborns were placed in plexiglass boxes flushed with 100\% oxygen for 6 days and untreated litters were maintained in room air. Nursing dams of $\mathrm{O}_{2}$ exposed litters and control litters were exchanged every $24 \mathrm{~h}$ due to the toxic effects of $\mathrm{O}_{2}$ on the adult rats. The animals were killed by decapitation, and the fetuses removed rapidly and placed on ice. Litter number in $\mathrm{O}_{2}$ and room air treatment groups were equalized to avoid any influence of litter size. The lungs were washed free of blood with chilled Krebs-Ringerphosphate buffer and subsequently prepared for biochemical studies or for explant culture. Hemoglobin content and the content of red blood cell glutathione was negligible against the background of lung glutathione. For glutathione and enzyme studies, lung tissue was pooled and homogenized $(1: 10 \mathrm{w} / \mathrm{v}$ dilution) in $50 \mathrm{mM}$ potassium phosphate buffer, $\mathrm{pH} \mathrm{7.8,} \mathrm{with} \mathrm{a}$ Teflon glass homogenizer. The crude homogenate was centrifuged at $700 \times g$ for 10 min to sediment nuclei and cell debris. A cytosol fraction was prepared by centrifugation at $18,000 \times g$ and subsequent recentrifugation of the supernate at $100,000 \times g$ for $60 \mathrm{~min}$. Aliquots were frozen for later analysis; glutathione was measured immediately.

Tissue culture. For experiments utilizing lung explants, fetuses were obtained from 18-to 19-day pregnant rats. The lungs were removed after decapitation of the fetus, washed in Krebs-Ringerphosphate buffer, and minced into $0.5-1.0 \mathrm{~mm}$ cubes using a Mcllwain tissue chopper. Lung explants were then cultured in Waymouth's MB 752/1 containing $100 \mathrm{mg} /$ liter gentamicin and $10 \%$ fetal calf serum at $37^{\circ} \mathrm{C}$ in humidified atmosphere in either $95 \% \mathrm{O}_{2}, 5 \% \mathrm{CO}_{2}$ or in room air, $5 \% \mathrm{CO}_{2}$ in sealed chambers. Human fetal lung explants were cultured under the same conditions. These materials were obtained from midtrimester (1218 wk postconceptional gestational age) human abortuses delivered electively by dilation and extraction. Tissues were obtained under the auspices of the Donors Anatomical Gift Act of the State of Texas after obtaining consent in writing from the woman undergoing abortion. The consent form as well as the experimental protocol were approved by the Human Research Review Committee of the University of Texas Southwestern Medical School. Five to seven explants (approximately $1 \mathrm{mg}$ protein) were placed in each $35 \mathrm{~mm}$ dish as described by Gross et al. (7), and the tissue culture media was changed daily.

Type II cells were prepared from $\mathrm{O}_{2}$-exposed and untreated rats by a modification of the method of Mason et al. (8) as described in detail elsewhere (9). Heparin sulfate (6 units/g) was injected intraperitoneally into 6-day-old rats $20 \mathrm{~min}$ prior to sacrifice. Neonatal rats were killed by cutting the abdominal aorta and the lungs were perfused with PBS to remove blood. The lungs were then lavaged at least four times until lavage fluid was clear with 7-10 ml of cold PBS containing $10 \mu \mathrm{g} / \mathrm{ml} \mathrm{BaSO} 4$ to permit removal of macrophages during the subsequent gradient centrifugation. The lungs were filled with $2-3 \mathrm{ml}$ of $0.2 \%$ trypsin plus $10 \mu \mathrm{g} / \mathrm{ml}$ DNase in PBS and incubated for $20 \mathrm{~min}$ at $37^{\circ} \mathrm{C}$. The trypsin solution was withdrawn and the lungs refilled with $0.1 \%$ trypsin inhibitor plus $10 \mu \mathrm{g} / \mathrm{ml} \mathrm{DNase}$ after 5 min. The tissue was minced using a Mcllwain chopper and again incubated with the trypsin inhibitor plus DNase after filtering through graded nylon meshes $(110,41$, and $15 \mu)$. The cells in trypsin inhibitor PBS $(20 \mathrm{ml})$ were layered on a discontinuous albumin gradient with refractory indices of $1.36,7 \mathrm{ml} ; 1.35,10$ $\mathrm{ml}$ and $1.34,5 \mathrm{ml}$. After centrifugation at $190 \times \mathrm{g}$ for $15 \mathrm{~min}$ at $4^{\circ} \mathrm{C}$, the cell fraction containing type II cells was collected from the interface of the 1.350 and 1.360 layers. The type II cells were further purified by differential adherence to plastic in minimum essential medium containing $10 \%$ fetal calf serum. Cells isolated under these conditions show greater than $95 \%$ viability as determined by Trypan blue exclusion. Approximately $3.0-4.5 \times 10^{6}$ cells per lung are obtained from air and $2.0 \times 10^{6}$ from $\mathrm{O}_{2}$ treated groups.

Assays. Total and reduced glutathione were measured as described by Griffith (10). G6PDH was assayed using the method of Lohr and Waller (11). SOD was determined by the method of Ysebaert-Vanneste and Vanneste (12) by measuring the inhibition of xanthine-xanthine oxidase reduction of ferricytochrome C. Glutathione reductase was monitored spectrophotometrically as described by Carlberg et al. (13) and glutathione peroxidase was determined by the method of Paglia and Valentine (14). Protein concentration was measured by the method of Lowry et al. (15) with bovine serum albumin as a standard.

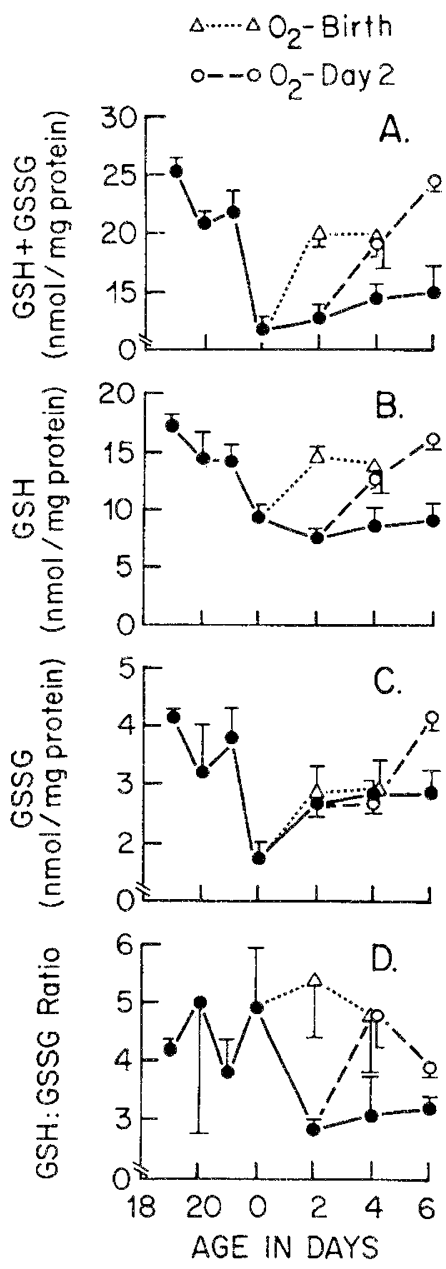

Fig. 1. $A-D$, effect of hyperoxia on glutathione content of neonatal rat lung. Values given are the means \pm SEM of at least 3 experiments. Rat pups were maintained in room air $(\bullet)$ or placed in $\mathrm{O}_{2}$ at birth $(\triangle)$ or at 2 days of age (O). $A$ shows GSH plus GSSG; $B, \mathrm{GSH}$; $C$, glutathione disulfide; $D$, GSH/GSSG ratio. 
Table 1. Glutathione content of human fetal lung explants exposed to hyperoxia*

\begin{tabular}{lcc}
\multicolumn{1}{c}{$\begin{array}{c}\text { Culture } \\
\text { conditions }\end{array}$} & \multicolumn{2}{c}{$\begin{array}{c}\text { GSH } \\
\text { nmol/mg protein }\end{array}$} \\
\hline Air & $12.97 \pm 0.95$ & $0.19 \pm 0.08$ \\
$95 \% \mathrm{O}_{2}, 5 \% \mathrm{CO}_{2}$ & $19.53 \pm 3.30$ & $0.35 \pm 0.005$ \\
\hline
\end{tabular}

* Effect of hyperoxia on the glutathione content of human fetal lung explants. Explants from three abortuses 12-16 wk were maintained in $95 \% \mathrm{O}_{2} .5 \% \mathrm{CO}_{2}$ for $72 \mathrm{~h}$. Conditions are as described in the text. Values given are the means \pm SEM of at least three experiments.

Table 2. Glutathione content of alveolar type II cells isolated from neonatal rats exposed to hyperoxia*

Glutathione

(nmol total GSH $/ 5 \times 10^{6}$ cell)

$\begin{array}{ll}\text { Air } & 0.26 \pm 0.08 \\ 100 \% \mathrm{O}_{2} & 0.59 \pm 0.03\end{array}$

* Total glutathione was measured in cells isolated from 6-day-old rats. Values given are the means \pm SEM of three experiments.

\section{RESULTS}

Glutathione status in developing lung. The glutathione content of rat lung was measured from day 19 of fetal development through the 6 th postnatal day. Developmental changes in lung glutathione content and changes in glutathione status in response to hyperoxia are shown in Figure $1 A-D$. As is shown in Figure $1 A$, total glutathione (GSH and GSSG) decreased from day 18 of gestation to the time of birth and then remained constant at approximately $11-14 \mathrm{nmol} / \mathrm{mg}$ protein for the next 6 days in the lungs of rat pups in room air. Pups placed in $100 \% \mathrm{O}_{2}$ at birth or at 2 days of age showed a rapid increase in lung glutathione content (Fig. $1 \mathrm{~A}$ ). This increase was due primarily to an increase in GSH concentration. Glutathione disulfide content increased postnatally and was the same in air- and $\mathrm{O}_{2}$-treated groups except that some litters exposed to $\mathrm{O}_{2}$ on day 2 showed higher GSSG by 6 days of age as compared with controls in air (Fig. 1C). The ratio of GSH/GSSG in the room air group declined postnatally (Fig. $1 D$ ) but remained high in the animals placed in $\mathrm{O}_{2}$ at birth. The ratio showed a rapid increase when animals were placed in oxygen at 2 days of age again reflecting the increase in lung GSH content after $\mathrm{O}_{2}$ exposure. Only after $48 \mathrm{~h}$ of $\mathrm{O}_{2}$ exposure did the GSH/GSSG ratio begin to decrease.

Table 1 shows the change in glutathione content of explants obtained from fetal human lung. For these experiments, explants obtained were maintained in $95 \%$ air, $5 \% \mathrm{CO}_{2}$ or $95 \% \mathrm{O}_{2}, 5 \%$ $\mathrm{CO}_{2}$ for $72 \mathrm{~h}$. Total glutathione (GSH plus GSSG) content increased from 14.2 to $26.7 \mathrm{nmol} / \mathrm{mg}$ protein in the $\mathrm{O}_{2}$ environment. This result was primarily due to an increase in GSH with a concomitant increase in the GSH/GSSG ratio.

The glutathione content of type II cells prepared from neonatal rats maintained in $100 \% \mathrm{O}_{2}$ from birth to 6 days of age was also 2 -fold larger $\left(0.59 \mathrm{nmol} / 5 \times 10^{6}\right.$ cells $)$ in animals maintained in oxygen for 6 days compared with room air controls $(0.26 \mathrm{nmol} /$ $5 \times 10^{6}$ cells) (Table 2). Because of limited amounts of cells available for these experiments, only the total glutathione (GSH plus GSSG) content was measured.

We also examined the influence of hyperoxia on the activities of enzymes associated with the glutathione status of the lung; namely, G6PDH, glutathione reductase, and glutathione peroxidase. Figure $2 A$ shows the developmental pattern of G6PDH in newborn rats placed in oxygen either at birth or 2 days of age as compared with animals in room air. G6PDH activity of newborns placed in $\mathrm{O}_{2}$ was consistently higher that that of room air controls.

The specific activity of glutathione reductase, the enzyme

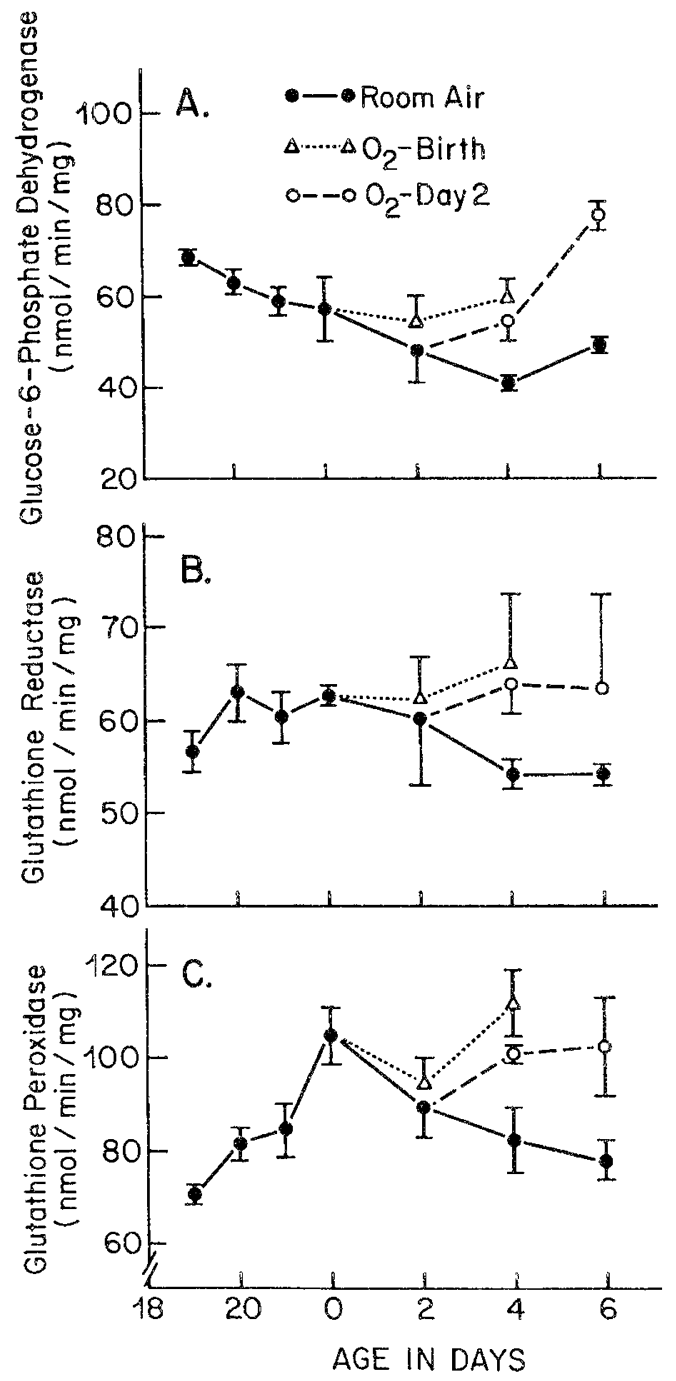

Fig. 2. $A-C$, effects of hyperoxia on G6PDH, glutathione reductase, and glutathione peroxidase activities of neonatal rats. Rat pups were placed in $100 \% \mathrm{O}_{2}$ at birth or at 2 days of age. Room air ()$; \mathrm{O}_{2}$ at birth $(\triangle) ; \mathrm{O}_{2}$ at 2 days of age $(\mathrm{O})$. Conditions are as described in the text.
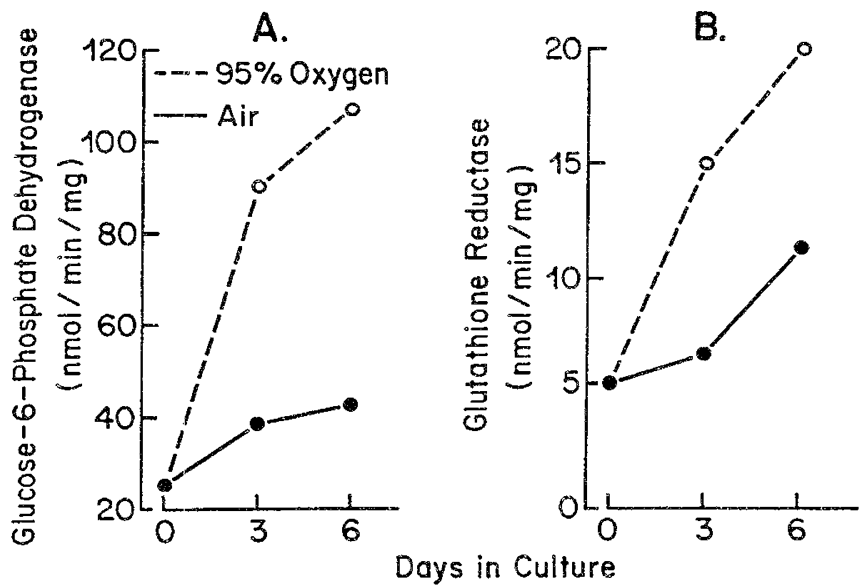

Fig. 3. $A$ and $B$, effect of hyperoxia on G6PDH and glutathione reductase in lung explants from 18-day gestation fetal rat lung. $95 \% \mathrm{O}_{2}$, $5 \% \mathrm{CO}_{2}(\mathrm{O})$; room air, $5 \% \mathrm{CO}_{2}(\bullet)$. Conditions are as described in the text. 
responsible for maintaining GSH in the cell, showed a pattern similar to G6PDH in response to hyperoxia (Fig. 2B). The postnatal activity of the enzyme was elevated in newborns exposed to $\mathrm{O}_{2}$ at birth or 2 days of age compared with room air controls. A similar profile was observed for glutathione peroxidase for $\mathrm{O}_{2}$-exposed pups (Fig. 2C).

Explants cultured from 18-day fetal rat lung and cultured in $95 \%$ air, $5 \% \mathrm{CO}_{2}$ for 5 days and then exposed to $95 \% \mathrm{O}_{2} 5 \%$ $\mathrm{CO}_{2}$ also showed a sharp increase in G6PDH activity after $72 \mathrm{~h}$ of exposure as compared with room air controls (Fig. $3 A$ ). Neonatal rat lung explants cultured under $95 \% \mathrm{O}_{2}, 5 \% \mathrm{CO}_{2}$ also exhibited increased glutathione reductase over $72 \mathrm{~h}$ of $\mathrm{O}_{2}$ exposure (Fig. $3 B$ ). Although not presented a similar pattern was observed for glutathione peroxidase and SOD.

\section{DISCUSSION}

In a study of the activity of selected enzymes involved in antioxidant protection in adult rat lung Kimbell et al. (16) showed oxygen-associated increases in glutathione peroxidase, glutathione reductase, and G6PDH. The concentration of GSH increased approximately 2 -fold over 14 days of exposure to $95 \%$ $\mathrm{O}_{2}$. Glutathione is also increased in perfused adult rat lungs exposed to oxidant stress (17). Cellular defenses against oxidant injury include the antioxidant enzymes SOD, the glutathione system, and $\alpha$-tocopherol (3). Developmental changes in pulmonary antioxidant systems have been well documented (1821 ). Our previous work (6) has demonstrated increases in glutathione reductase, glutathione peroxidase, and SOD in lung of newborn rabbits exposed to $100 \%$ oxygen for $72 \mathrm{~h}$. These animals were maintained on an artificial diet and were likely vitamin $\mathrm{E}$ deficient. Administration of pharmacological amounts of vitamin $E$ to rabbits maintained at $100 \%$ oxygen blunted the oxygen dependent increase in antioxidant enzyme activity, likely by providing sufficient antioxidant protection to limit the stimulus for the adaptive increase of the antioxidant protective enzymes (6).

While there has been considerable work on antioxidant enzymes during lung development, relatively little is known of the glutathione response in developing lung. In the present study, we demonstrated a brisk and rapid increase in glutathione levels in tissues obtained from oxygen-exposed neonatal rats and after in vitro oxygen exposure of explants and cells. These changes in GSH likely relate to an increase in de novo synthesis in lung of GSH (Saito K, Warshaw J, unpublished observation), as well as to maintenance of the high GSH/GSSG ratio through the concerted activities of G6PDH and glutathione reductase. The increase in total glutathione after exposure of newborn rats to $100 \% \mathrm{O}_{2}$ or culture of lung explants in $95 \% \mathrm{O}_{2}$ occurred rapidly and was primarily due to an increase in GSH. Our data showing oxygen induced increases in GSH levels and in glutathione peroxidase and reductase activity of newborn rats are in agreement with those reported by Yam et al. (20). We also found increased activity of enzymes linked to the glutathione system. G6PDH activity of animals maintained in oxygen as well as activity of explants grown in oxygen showed a rapid and sustained increase in specific activity during oxygen exposure. NADPH generated by G6PDH provides reducing equivalents for the reduction of GSSG to GSH by glutathione reductase. In a reaction catalyzed by glutathione peroxidase, GSH provides substrate for the reduction of damaging lipid peroxides in membranes.

The strategy of the cell appears to be directed toward maintaining a high GSH to GSSG ratio $(22,23)$. Our data indicate that in neonatal lung exposed to hyperoxic stress, there is a concerted increase in the activity of enzymes responsible for maintenance of glutathione in the reduced state, as well as an absolute increase in the intracellular concentration of glutathione itself. The nature of the stimulus responsible for increased levels of GSH in lung is unclear. Since the initial response to hyperoxia is directed toward maintaining high concentrations of GSH relative to GSSG, a decrease in GSH to GSSG ratio could stimulate increasd glutathione production under conditions of hyperoxia. In our study, newborn animals maintained in oxygen for more than $48 \mathrm{~h}$ showed a decrease in the GSH to GSSG ratio (Fig. 1D), possibly indicating that the capacity for continued synthesis of glutathione and its maintenance as GSH was limited under prolonged conditions of oxidative stress.

Loss of GSSG from the cell may also lead to increased synthesis of glutathione (24). $\gamma$-Glutamyl transpeptidase, one of the enzymes associated with glutathione degradation, also increases in activity in neonatal lung in response to oxidant stress (Saito K, Warshaw J, unpublished observations), so that increased glutathione degradation may provide another mechanism for removal of GSSG from the cell. GSSG excretion into the bile was shown to be a sensitive index of oxidative stress in vivo (24). Loss of glutathione by this route would increase requirements for GSH synthesis and maintenance of high levels of the reduced form of this compound.

Bucher and Roberts (18) reported a slowing of alveolar development during hyperoxia including a decrease in lung DNA content. We have reported similar results relating to lung growth of hyperoxic animals (25). Since proliferative growth has been associated with increases in G6PDH activity (26), it would appear that in the case of growth-restricted lungs of oxygen-treated animals that the increase in G6PDH activity may be utilized to support antioxidant systems, rather than for synthetic processes such as fat or nucleotide synthesis.

We observed somewhat similar responses of antioxidant systems in vivo or in lung explants. Glutathione levels, as well as activity of antioxidant enzymes, increased in both systems in response to hyperoxia. Although $\mathrm{O}_{2}$ exposed and room air cultured explants did not show histological differences, it is possible that some of the differences observed reflected relative hypoxia of room air exposed explants as well as induction of enzyme activity by oxygen. Type II cells obtained from oxygen-treated neonatal rats showed higher levels of glutathione after their isolation than cells obtained from animals maintained in room air. Since changes in both glutathione and in antioxidant enzymes were found in lung explants as well as after in vivo $\mathrm{O}_{2}$ exposure, it does not appear that the changes observed are due to a general endocrine response as for example glucocorticosteroids. The brisk and rapid increase in the GSH content observed in explants and total glutathione levels of type II cells obtained from oxygen-treated rats suggests that this response is intrinsic to lung itself and not related to synthesis of glutathione in liver or to a signal from another organ or cell type elsewhere in the body.

\section{REFERENCES}

1. Taghizadeh A, Reynolds EOR 1976 Pathogenesis of bronchopulmonary dysplasia following hyaline membrane disease. Am J Pathol 82:241-264

2. Brown ER 1979 Increased risk of bronchopulmonary dysplasia in infants with patent ductus arteriosus. J Pediatr 95:865-866

3. Ehrenkranz RA, Ablow RC, Warshaw JB 1978 Oxygen toxicity: the complications of oxygen use in the newborn infant. Clin Perinatol $5: 437-450$

4. Bonikos DS, Bensch KG, Northway WH Jr, Edwards DK 1976 Bronchopulmonary dysplasia: the pulmonary pathologic sequela of necrotizing bronchiolitis and pulmonary fibrosis. Hum Pathol 7:643-666

5. Ehrenkranz RA, Warshaw JB 1983 Chronic lung disease in the newborn. In: Stern L (ed) Diagnosis and Management of Respiratory Disorders in the Newborn. Addison-Wesley, Menlo Park, CA pp 84-109

6. Wender DF, Thulin GE, Smith GJW, Warshaw JB 1981 Vitamin E affects lung biochemical and morphological response to hyperoxia in the newborn rabbit. Pediatr Res 15:262-268

7. Gross IG, Smith JW, Maniscalco WM, Czajka MR, Wilson CM, Rooney SA 1978 An organ culture model for study of biochemical development of fetal rat lung. J Appl Physiol 45:355--362

8. Mason MC, Williams RJ, Greenleaf RD, Clements JD 1977 Isolation and properties of type II alveolar cells from rat lung. Am Rev Respir Dis 115:1015-1016

9. Saito K, Lwebuga-Mukasa J, Barrett C, Light D, Warshaw JB 1985 Characteristics of primary isolates of alveolar type II cells from neonatal rats. Exp Lung Res (in press) 
10. Griffith OW 1980 Determination of glutathione and glutathione disulfide using glutathione reductase and 2-vinylpyridine. Anal Biochem 106:207-212

11. Lohr GW, Waller HD 1974 In: Bergmeyer HU (ed) Methods of Enzymatic Analysis, Vol 2. Academic New York, pp 636-643

12. Ysebaert-Vanneste M, Vanneste WH 1980 Quantitative resolution of $\mathrm{Cu}, \mathrm{Zn}$ and Mn-superoxide dismutase activities. Anal Biochem 107:86-95

13. Carlberg I, Altmejd B, Mannervik B 1981 Purification and immunological studies of glutathione reductase from rat liver. Biochim Biophys Acta $677: 146-152$

14. Paglia DE, Valentine WN 1967 Studies on the quantitative and qualitative characterization of erythrocyte glutathione peroxidase. $J$ Lab Clin Med $70: 158-169$

15. Lowry OH, Rosebrough NJ, Farr AL, Randall RJ 1951 Protein measurement with the Folin phenol reagent. J Biol Chem 193:265-275

16. Kimbell RE, Reddy K, Peirce, TH, Schwartz LW, Mustafa MG, Cross CE 1976 Oxygen toxicity: augmentation of antioxidant defense mechanisms in rat lung. Am J Physiol 230:1425-1431

17. Nishiki K, Jamieson D, Oshino N, Chance B 1976 Oxygen toxicity in the perfused rat liver and lung under hyperbaric conditions. Biochem J 160:343355

18. Bucher J, Roberts R 1981 The development of the newborn rat lung in hyperoxia: a dose-response study of lung growth maturation, and change in antioxidant enzymes activities. Pediatr Res 15:999-1008

19. Frank L, Bucher JR, Roberts RJ 1978 Oxygen toxicity in neonatal and adult animals of various species. J Appl Physiol 45:699-704

20. Yam J, Frank L, Roberts RJ 1978 Oxygen toxicity: comparison of lung biochemical responses in neonatal and adult rats. Pediatr Res 12:115-119

21. Kehrer JP, Autor AP 1977 Age-dependent lipid peroxidation in neonatal rat lung tissue. Arch Biochem Biophys 181:73-81

22. Orrenius S, Ormstad K, Thor H, Jewell SA 1983 Turnover and functions of glutathione studied with isolated hepatic and renal celis. Fed Proc 42:31773188

23. Lauterburg BH, Smith CV, Hughes H, Mitchell J 1984 Biliary excretion of glutathione and glutathione disulfide in the rat: regulation and response to oxidative stress. J Clin Invest 73:124-133

24. Yam J, Frank L, Roberts RJ 1978 Age-related development of pulmonary antioxidant enzymes in the rat. Proc Soc Exp Biol Med 157:293-396

25. Kimura RE, Thulin GE, Wender D, Warshaw JB 1983 Decreased oxidative metabolism in neonatal rat lung exposed to hyperoxia. J Appl Physiol Physiol 55:1501-1505

26. Warshaw JB, Rosenthal MD 1972 Changes in glucose oxidation during growth of embryonic heart cells in culture. J Cell Biol 52:283-291

\title{
Modulation of Glucocorticoid Secretion by Growth Hormone
}

\author{
FRED I. CHASALOW AND SANDRA L. BLETHEN
}

The Edward Mallinckrodt Department of Pediatrics, Washington University School of Medicine, Division of Endocrinology and Metabolism, St. Louis Children's Hospital, St. Louis, Missouri 63178 and the Division of Pediatric Endocrinology, Schneider Children's Hospital of Long Island Jewish Medical Center,

New Hyde Park, New York 11042

\begin{abstract}
We measured the cortisol and corticosterone responses to insulin-induced hypoglycemia in 13 growth hormone $(\mathrm{GH})$-deficient children and 30 short children without GH deficiency. Although there was no difference between the two groups in 1) degree of hypoglycemia attained, 2) baseline cortisol, 3) baseline coricosterone, or 4) cortisol $40 \mathrm{~min}$ after insulin injection, GH-deficient children had a significantly greater corticosterone response to this stress $(3.6 \pm 0.4$ versus $1.9 \pm 0.2 \mu \mathrm{g} / \mathrm{dl}$ ). (All data are presented as mean \pm SEM.) In order to explore the effect of GH on corticosterone secretion, we measured cortisol and corticosterone responses to synthetic (1-24) ACTH before and after 3 days of exogenous $\mathrm{GH}(0.2$ unit/ kg/day). In 13 GH-deficient children, GH treatment caused a significant decrease in the corticosterone response to ACTH $(2.2 \pm 0.2 \mu \mathrm{g} / \mathrm{dl}$ before $\mathrm{GH}$ to $1.6 \pm 0.2 \mu \mathrm{g} / \mathrm{dl} ; t=$ $5.22, p<0.001$; paired $t$ test) despite the fact that there was no significant change in the cortisol response to $\mathrm{ACTH}$ $(18 \pm 2 \mu \mathrm{g} / \mathrm{dl}$ before and $16 \pm 2 \mu \mathrm{g} / \mathrm{dl}$ after). When seven short children who were not $\mathrm{GH}$ deficient underwent a
\end{abstract}

Received February 11, 1985; accepted March 25, 1985

Requests for reprints to Fred I. Chasalow, Ph.D., Division of Pediatric Endocrinology, Schneider Children's Hospital of Long Island Jewish Medical Center, New Hyde Park, NY 11042

Supported in part by RR-36 from the General Clinical Research Centers Program of the Division of Research Resources of the NIH and by AM05105. similar 3-day course of GH, the decrease in their corticosterone response was much less although still statistically significant $(2.0 \pm 0.5$ to $1.8 \pm 0.5 \mu \mathrm{g} / \mathrm{dl}$; paired $t$ test, $p<$ $0.05)$. Again, the stimulated levels of cortisol were not affected by $\mathrm{GH}$ treatment $(19 \pm 4$ versus $18 \pm 3 \mu \mathrm{g} / \mathrm{dl})$ These results indicate that $\mathrm{GH}$ modulates the adrenal response to ACTH by suppressing corticosterone secretion without affecting cortisol secretion. In summary, this study presents two new findings. First, corticosterone levels are elevated during insulin tolerance testing in children with GH deficiency and, second, a 3-day course of GH replacement therapy causes a reduction in corticosterone serum levels after ACTH administration to more normal levels without altering the corresponding cortisol concentrations. As corticosterone is a less potent glucocorticoid, it might function as a cortisol antagonist when present in increased amounts and play a role in the poor recovery from hypoglycemia frequently observed in individuals with $\mathrm{GH}$ deficiency. (Pediatr Res 19: 823-827, 1985)

\section{Abbreviations}

GH, growth hormone

ACTH, adrenocorticotropic hormone

RIA, radioimmunoassay

SmC, somatomedin C 